ECOLOGY AND SOCIETY

Home | Archives | About | Login | Submissions | Notify | Contact | Search

ES HOME > VOL. 2, NO. 2 > ART. 18

Copyright $@ 1998$ by The Resilience Alliance*

Schindler, D.W. 1998. Sustaining aquatic ecosystems in boreal regions. Conservation Ecology [online] 2(2): 18. Available from the Internet. URL: http://www.consecol.org/vol2/iss2/art18/

A version of this article in which text, figures, tables, and appendices are separate files may be found by following this link.

Synthesis, part of Special Feature on Sustainability and Resilience in Boreal Regions

\title{
Sustaining Aquatic Ecosystems in Boreal Regions
}

David W. Schindler

\section{University of Alberta}

- Abstract

- Introduction

- Natural Variation in Boreal Lakes and Streams

- Interactions of Lakes and Streams with their Catchments

- Natural Biodiversity in Boreal Streams and Lakes

- The Effects of Climate Variation on Boreal Aquatic Species

- The Effect of Indigenous Peoples

- Modern Boreal Management and Ecological Variability

- Fisheries Management

- Ecological Invasions

- Reservoir Building

- Changes to Aboriginal Communities: Clear Evidence of Nonsustainable Activity

- Pollutant Discharges

- Human Activities in Catchments

- Human Alterations to the Atmosphere that Affect the Boreal Region

- Building a Sustainable Economy in Boreal Regions

- Responses to This Article

- Acknowledgments

- Literature Cited

\section{ABSTRACT}

Few boreal waters are managed in a sustainable manner, because cumulative effects of a variety of human activities are not considered. Fisheries and water quality have declined in most large water bodies of the southern boreal zone. Some of the reasons are direct, including overexploitation of fisheries, alteration of flow patterns, introductions of non-native species, and discharge of eutrophying nutrients and persistent contaminants. However, improper management of watersheds and airsheds also causes degradation of aquatic ecosystems. Clear-cut logging, climatic warming, acid precipitation, and stratospheric ozone depletion are among the more important of these indirect stressors. There are important interactions among these stressors, requiring that they not be treated in isolation. Ecological sustainability of boreal waters would require that exploitation of all parts of the boreal landscape be much lower than it is at present. Unfortunately, management for sustainability is lagging far behind scientific understanding in most countries.

KEY WORDS: atmospheric stressors, aquatic ecosystems, biodiversity of streams and lakes, boreal ecosystems, clear-cutting, cumulative effects, ecological invasions, fisheries, indigenous peoples, 
land-water interactions, sustainable development, watershed management.

\section{INTRODUCTION}

Softwater boreal lakes, underlain by ancient igneous rocks, are the most numerous of any lake type on Earth. For example, the region of Canada east of the Manitoba-Ontario border and south of $52^{\circ}$ north latitude contained over 600,000 lakes $>4$ ha in area (Minns et al. 1992). Northern Manitoba, Saskatchewan, Alberta, and much of the Northwest Territories contain similar densities of lakes. Northern Minnesota, Wisconsin, and Michigan also contain boreal lakes. In Eurasia, much of northern Russia and Scandinavia contain large numbers of boreal lakes. Altogether, there are probably at least 2 million of them, ranging in size from small ponds to Lake Superior, Lake Winnipeg, Great Slave, Great Bear, Lake Nipigon, and Lake Baikal. Altogether, softwater boreal lakes may contain $80 \%$ or more of the world's unfrozen freshwater.

Many of the world's great northern rivers also flow, wholly or in part, through boreal regions. In North America, much of the Peace-Athabasca-Mackenzie and Saskatchewan-Winnipeg-Nelson river systems flow through the boreal zone, carrying water to the Arctic and Atlantic Oceans, repectively. There are several boreal rivers of similar or even greater size in the Soviet Union. In addition, there are many other rivers of several hundred kilometers in length. Shorter river and stream segments interconnect lakes and drain catchments containing wetlands or forests. In addition, the boreal region contains the majority of the world's freshwater wetlands, if subarctic, open lichen woodlands are included (Gorham 1991).

Because of the many watercourses, exposed igneous rock, cold climate, and huge size, exploitation before the mid-20th century had been limited largely to the extreme southern edge of the boreal region in North America. However, as lumber, fisheries, and mineral resources in other regions were depleted and transportation improved, eyes turned to the vast boreal region. The last 40 years have seen rapid, poorly controlled, and poorly planned development. There has been no attempt to assess cumulative effects of human activity in the region, or to take an integrated approach to managing boreal resources.

In what follows, I attempt to document what is being lost as the more pristine parts of the boreal region are exploited, what some of the major stresses are, and how they interact. Although my experience and examples are confined largely to North America, similar exploitation and interactions are occurring in the Soviet Union. Much of the Scandinavian and U.S. boreal has already been exploited. Forests and waters are intensively managed, but little area remains in a near-pristine state.

\section{NATURAL VARIATION IN BOREAL LAKES AND STREAMS}

Boreal waters have features that are predictable on a variety of time scales. Most boreal lakes occur in continental climates, where spring and autumn transitions are rapid, but somewhat variable and unpredictable. In small lakes, ice can leave and thermal stratification can set in the same day, with resulting incomplete spring turnover, increasing the eventual oxygen deficit and build-up of ammonium, methane, $\mathrm{CO}_{2}$, and other chemicals in hypolimnions. Similarly, unpredictable early fall snowstorms can cool lakes rapidly with heavy snowfalls, often with ice cover forming soon after. As a result, meromixis or near-meromixis is very common in small, deep lakes.

Near-headwater rivers typically have maximum flows in spring, corresponding with snowmelt. The maximum flows occur later in larger rivers, where several weeks are required to accumulate maximum meltwaters from tributaries. Minimum flows typically occur in late fall and winter.

In some years, boreal lakes can cool early, destratifying but not freezing, which results in several weeks of mixing that completely eliminates residual oxygen deficits, ammonium and methane build-ups, etc. This is more common in autumn than in spring, and in larger, deeper lakes (with their larger thermal capacities) than in small lakes, which respond more immediately to weather.

Size is perhaps a more important predictive variable for lakes than for other types of boreal ecosystems. The importance of fetch on thermodynamics is well known, with advective properties, internal waves, and other processes becoming increasingly important in larger lakes (Fee and Hecky 1992, Imberger 1994). As a result, although general biological and chemical properties of large and small lakes are somewhat similar (but with larger lakes tending to have higher diversity; Schindler 1990a), many lacustrine properties require size-scaling to extrapolate accurately from small to large systems, as shown by the NOLSS (Northern Ontario Lake Size) Study (Fee and Hecky 1992; see Canadian Journal of Fisheries and Aquatic Sciences volumes 49 (12), 50 (5), and 51 (12)).

\section{INTERACTIONS OF LAKES AND STREAMS WITH THEIR CATCHMENTS}


Boreal ecosystems show considerable long-term variation, even in the absence of modern human activity. Both paleoecological studies (Wright and Heinselman 1973, Ritchie and Yarranton 1978, Payette et al. 1989) and long-term studies of boreal lakes and streams in remote areas (Schindler et al. 1990, 1996a,b, 1997) show that boreal terrestrial ecosystems are strongly affected by natural phenomena such as fire, windthrow, and insect outbreaks, which in turn are strongly affected by climate and weather. Lakes and streams are affected by these terrestrial disasters, as well as directly by climate and weather (Wright 1976, Schindler et al. 1980, 1990, Bayley et al. 1992a, b, Schindler 1998).

As a rule of thumb, fires occur at average intervals of about 80-100 years in midcontinental boreal systems, (Heinselman 1973, Swain 1973), although the actual fire frequency at a given site can range from a few years to 200 years or more. Also, fires tend to occur during periods of warm weather and drought, which can affect lakes even more than does fire (Schindler et al. 1996a). As a result, over decades, there can be rather large and important variations in physical, chemical, and biological properties of lakes and streams (Schindler et al. 1996a). Understanding these intersystem linkages is important, for as I shall discuss later, many of the threats to the sustainability of lakes and rivers can be traced to human activities in their catchments.

There is not typically a "senescent" phase in boreal forest development that can affect the chemical composition of streams and lakes in their catchments. Instead, forest systems appear to accumulate biomass and nutrients continuously until interrupted by fire or other disturbance. Following fire, increases in chemical and hydrological outputs from streams draining the burned areas last from a few to several years, depending on the severity and season of fire, climate, and weather (Schindler et al. 1980, 1996a, Bayley et al. 1992a,b).

Not surprisingly, fire also alters the seasonal dynamics of water and chemicals, especially in streams and small lakes. Burned catchments have higher streamflows and water and nutrient concentrations for several years following fire, with the greatest changes following the most severe burns (Wright 1976, Bayley et al. 1992a). Yields of base cations ( $\mathrm{Ca}, \mathrm{Mg}, \mathrm{Na}, \mathrm{K}$ ) increased after fire, but increases in strong acid anions $\left(\mathrm{SO}_{4}, \mathrm{NO}_{3}, \mathrm{Cl}\right)$ were even greater, causing a net acidifying effect on streams (Bayley et al. 1992b).

Conversely, lakes in burned areas had declining concentrations of phosphorus. Base cations, especially calcium, and strong acid anions, especially sulfate, increased, but due to sulfate reduction and removal in lake sediments, lakes became more alkaline, even in catchments where fire had caused inflow streams to become more acidic. Almost all of the observed increase in buffering capacity can be attributed to the difference in concentration between calcium and sulfate (Schindler et al. 1996a).

In general, the larger the catchment and the shallower the lake, the greater the influence of the catchment on water quality. Many average properties of boreal lakes are quite predictable functions of the ratio of basin area to lake area, or basin area to lake volume (Schindler 1971, Engstrom 1987, Rasmussen et al. 1989, Curtis and Schindler 1997). As a rule of thumb, catchment:lake area ratios of 10:1 are average for headwater lakes, although there is considerable variation. At such a ratio, precipitation supplies about $50 \%$ of the total nitrogen and phosphorus to lakes, with catchments supplying the other $50 \%$. Despite the catchment's larger size, removal of these nutrients by forest and wetland vegetation usually decreases yields to water by $90 \%$ or so (Schindler et al. 1976). Typically, the nitrogen and phosphorus released from catchments to lakes is $>80 \%$ in dissolved, organic form. These are rough estimates; catchment: lake area ratios can vary from 1:1 to over 100:1. Lakes with larger catchment: volume ratios also have shorter water renewal time, so that they respond more rapidly to changing inputs of chemicals, whether they be natural in origin or contaminants. As a rule of thumb, following changes in chemical inputs or water flows, three water renewal times are required to approach a new steady state, where water renewal time in years is simply the lake volume divided by annual outflow volume.

Boreal forest plant communities are well adapted to periodic fire (Wright and Heinselman 1973). Natural fires generally follow other disasters such as windthrow or insect outbreaks, which cause buildups of dead, dry fuel that increase. These are typically ignited by lightning, following warm, dry weather (Heinselman 1973). However, there are positive feedbacks: warm, dry conditions are known to promote or enhance insect outbreaks in boreal forests (Kurz et al. 1995). In most cases, the effects of fire on streams and lakes are rather small, because the low topographic relief, shallow overburden, and weathering-resistant bedrock limit losses of silt and dissolved chemicals (Bayley et al. 1992a,b, Beaty 1994).

The role of wetlands deserves special mention, for they affect properties of streams and lakes in different ways than do upland systems. Much of the DOC (dissolved organic carbon) entering lakes and streams, which, as I shall discuss later, has very important effects on physical, chemical, and biological properties, originates in wetlands rather than uplands (Engstrom 1987, Urban et al. 1989). Also, wetlands intercept and sequester much of the sulfate and nitrate entering catchments in precipitation, whether the origins are natural or anthropogenic. The sulfate is reduced and sequestered in organic form (Bayley et al. 1986, Rochefort et al. 1990). This mechanism offers partial protection to downstream waters from sulfuric acid in precipitation. However, if drought causes water levels in wetlands to decrease, some of the sulfur is reoxidized to sulfate, causing acid pulses in downstream waters following sudden rainstorms (Bayley et al. 1992b, Lazerte 1993). Wetlands also appear to be efficient sinks for 
entering nitrate. Under natural conditions, $<1 \%$ of entering nitrate escapes to downstream waters (S.E. Bayley, unpublished data). With the increase in deposition of nitrate observed throughout the western world (Howarth 1996, Vitousek et al. 1997), wetlands may also protect downstream waters from the full effects of nitric acid. Little of the nitrogen entering boreal wetlands appears to be denitrified, with most of it promoting growth of Sphagnum and other wetland species (S.E. Bayley, unpublished data).

Fire disrupts these protective mechanisms, causing increases in the concentration of sulfate and nitrate in streams from boreal catchments by severalfold, for several years following the fire (Bayley et al. 1992b). Yields of both ions can also increase in excess of increased yields of base cations, causing an acidifying effect (Bayley et al. 1992b.). However, prolonged drought can cause streamflows to be decreased enough to cause reduced yields, even when concentrations are high (Schindler et al. 1996a).

Thus, biogeochemical processes in the catchments of lakes can protect or amplify the inputs of key nutrients and other ions to freshwaters under natural perturbation. As I shall discuss, these same processes can modify the effects of human perturbations.

\section{NATURAL BIODIVERSITY IN BOREAL STREAMS AND LAKES}

When compared to temperate or tropical lakes, particularly in richer geological settings and unglaciated regions, boreal freshwaters contain few species (Schindler 1990a). Their simple communities make them very vulnerable to perturbations. Small lakes often have a single predatory species of fish, no piscine predators, or even no fish at all. Lakes are unproductive, so that numbers of fish can be very small, with predators often only present at $0.01-1$ animal/1000 $\mathrm{m}^{2}$ of lake area. Recruitment in many species occurs sporadically, often with a good year class only every 7 or 8 years (Healey 1978, 1980). Fish tend to grow toward an asymptotic size that differs from lake to lake, depending on some unknown combination of lake productivity, abundance of prey, and numbers of predators. Typically, reproductive size in predatory species is reached in 4-6 years, with only slow additional growth as fish age, often to 20 or $30+$ years. After fish reach maturity, much of the year's energy intake is used in reproduction. Only the largest lakes contain more than one or two predatory fish species. Growth is so slow that, until recently, it was very difficult to age fish. Consistent underestimates of age using traditional scale-ageing techniques caused fisheries scientists to greatly overestimate the fish production of such lakes earlier in the 20th century, leading to frequent overexploitation of boreal fish stocks (Mills and Chalanchuk 1988).

Other parts of boreal aquatic communities are equally poor in species. Only a few species of large benthic crustaceans are found. At Experimental Lakes Area (ELA), northwestern Ontario, small lakes often have only a single crayfish species, Orconectes virilis, Hyalella, and Mysis. If these species are eliminated, there is no replacement by other species with similar food or habitat requirements, i.e., they have low functional redundancy (Schindler 1988a, Frost et al. 1995, Schindler et al. 1996a ). Overall, most boreal aquatic communities probably contain no more than a few hundreds of readily identifiable species on any single date (Schindler et al. 1989). However, the total species assemblage in a lake that is available to adapt to changing conditions is difficult to estimate, because many species are too rare to sample. Others have resting stages in sediments, and there is a continuous flux of invaders from upstream or other nearby lakes. It is not uncommon for new species to appear in the plankton and benthos without warning, even if they have not been detected by a decade of intensive monitoring. These offer the potential to respond to perturbations caused by humans, and to recover after perturbations are removed (Malley et al. 1982, Findlay and Kasian 1986, 1987, 1990, 1996, Bilyj and Davies 1989, Schindler et al. 1991).

Because they contain such small numbers of species, boreal ecosystems have been largely ignored by those concerned with declining biodiversity. As I have argued earlier (Schindler 1996a), this makes no sense from an ecosystem standpoint. The few species present in boreal systems perform the same basic biogeochemical functions (photosynthesis, respiration, biogeochemical cycling, fueling food chains that lead to humans or to valued species at higher trophic levels) as the much more complex tropical and subtropical ones. To use Ehrlich's "rivet" analogy, removing a few species from a boreal ecosystem that contains only hundreds of species seems much more likely to compromise vital community and ecosystem functions than does removal of the same number of species from a tropical ecosystem that contains hundreds of thousands of taxa. The disappearance of only a few species has been shown to impair the proper functioning of food chains and biogeochemical functions in boreal lakes at ELA (Schindler et al. 1985a, 1991, Rudd et al. 1988, Schindler 1988b, 1990b). In brief, loss of biodiversity from naturally impoverished boreal ecosystems deserves much more attention than it has received.

\section{EFFECTS OF CLIMATE VARIATION ON BOREAL AQUATIC SPECIES}

Many boreal aquatic species are well known for their poor tolerance of warm temperatures or low oxygen. High proportions of fishes and invertebrate species are known to be "cold stenotherms," probably because their glacial history has seldom exposed them to water temperatures in excess of the high teens. Well-known examples include 
lake trout, lake whitefish, opposum shrimp, and Diporeia (see Dadswell 1974 for more detailed information). In more southerly boreal lakes, such organisms survive by staying below the thermoclines of lakes during summer months. Climate-warming threatens populations in smaller lakes by decreasing their summer cold-water habitats as the result of increasing thermocline depths. This change results from decreasing concentrations of dissolved organic carbon (DOC) in the water, which allows increased solar penetration (Schindler et al. 1990, 1996a). Increasing hypolimnetic oxygen depletion, whether caused by smaller hypolimnions, longer stratified periods, or increasing rates of decomposition, could further deplete summer habitat for cold stenotherms, because most species are also intolerant of low oxygen (Schindler et al. 1996a). Mass fish mortalities can result. For example, the cisco (Coregonus artedii) will move out of hypolimnions with low oxygen into epilimnions, even if their lethal temperature of $24^{\circ} \mathrm{C}$ is exceeded as a result (Colby and Brooke 1969, Rudstam and Magnuson 1985). During the summer of 1998, the warmest on record, massive mortalities of lake whitefish Coregonus clupeaformis in large boreal lakes of central Alberta were attributed to low oxygen in the hypolimnions of lakes (Government of Alberta, Fisheries and Wildlife Management Division press release, 27 August 1998). In unexploited Lake 239 at Experimental Lakes Area (ELA), nearly 30 years of records show a slow decline in lake trout and an increase in northern pike as cold-water habitat has declined. (Schindler et al. 1996a; K.H. Mills, personal communication).

In larger lakes, the thermocline depth is deep as a result of fetch and surface winds, so that changes in transparency have little effect (Fee et al. 1996). Concerns for cold-water fisheries in such lakes are somewhat different. Many of North America's most productive cold-water lakes are only weakly stratified, so that there are no subthermocline summer refuges. Cold-water species are able to thrive in such lakes because surface water temperatures seldom exceed the mid-to-high teens. Even a slight climatic warming can cause the temperatures in these lakes to exceed the thermal tolerance of cold stenotherms.

Until a few years ago, we assigned rather narrow thermal tolerances to lake trout, based on a few laboratory studies; now, however, we know that there is wide lake-to-lake variation in the thermal tolerance and preference of lake trout populations, at least in small lakes (Sellers et al. 1998). This suggests that some of the adverse effects of climatic warming might be ameliorated by the stocking of temperature-tolerant strains of species that are native to the region into water bodies where indigenous stocks are not very tolerant. This possibility has not been widely explored. As a precautionary note, many lakes in North America were stocked with non-native species or genetic stocks earlier in the century in order to "improve" native stocks in one way or another. In many of these cases, the "improvements" were accompanied by adverse effects on communities or ecosystems, due to changed habitat or food requirements of the introduced stocks. I am therefore reluctant to endorse widespread stocking as a panacea for the adverse effects of climate warming.

Although we cannot say with certainty that these observations result from increased greenhouse gas emissions, or whether they are part of a natural climatic cycle, the warming trend in the central and western boreal has now lasted almost 30 years. The increase in average air temperatures has been about half of what is predicted for a doubling of atmospheric $\mathrm{CO}_{2}$. Thus, the ELA studies provide an interesting preview of what full greenhouse warming may bring. However, even if greenhouse warming is less than expected, it is clear that natural variations in climate can cause changes that are extreme enough to be considered when planning human management of resources, whether they be logging, fisheries, or water use.

\section{THE EFFECT OF INDIGENOUS PEOPLES}

Aboriginal peoples have occupied boreal regions for thousands of years. It is common to find campsites, rock paintings, and other evidence of pre-European human activity along boreal lakes and rivers, which served as natural migration routes and important sources of food. Clearly, aboriginal peoples also used fire as a "management and enhancement" tool, to improve grazing, browsing, habitats, or hunting conditions for preferred species of wildlife by rejuvenating primary successional species, much as they did in other regions (Lewis 1977, Lewis and Ferguson 1988, Kay 1994). Although there are no detailed records that I know of, it seems logical that aboriginals, as well as modern humans, also set fires accidentally. There is increasing realization that indigenous peoples had more influence on landscapes and wildlife populations than we recognized even a few decades ago. It is reasonable to expect that aboriginal burning had the same effects on lakes and streams as those just documented; indeed, their activities must be considered as a part of "natural variation." Even today, elders from indigenous communities can recount past uses of the landscape, with areas of several hundreds of square kilometers around settlements providing fish, berries, meat, or fur (Flett et al. 1996). Even when the resources harvested were terrestrial, access and transportation in boreal regions was typically via lakes or streams. The importance of these waterways is documented by Robinson (1879), Hopwood (1971), and Newman (1987).

The arrival of Europeans changed the habits of indigenous peoples in ways that affected the boreal landscape long before industrial development occurred. Many of the people in boreal regions turned to trapping of small furbearers, which were not previously of high importance to their economies. These were traded to the Hudson's Bay Company and other fur companies and to private traders in exchange for European goods, including steel traps and rifles that increased their impacts on wildlife. These transitions in lifestyle were documented in great detail by 
early explorers such as Samuel Hearne, John Richardson, and David Thompson, who traveled widely in the boreal region with native people in the 18th century (Coues 1897, Hopwood 1971). Their journals describe the much greater impacts on wildlife of steel guns and traps than of the traditional weapons, snares, and deadfalls used earlier. Thompson (in Hopwood 1971) relates the rapid effect of the 1793 introduction of steel traps on the beaver and native populations of an eastern boreal region: " For several years all these Indians were very rich; the women and children, as well as the men, were covered with silver broaches, earrings, wampum, beads and other trinkets. Their mantles were of fine scarlet cloth, and all was finery and dress. Four years after (1797), almost the whole of these extensive countries were denuded of beaver, the natives became poor, and with difficulty procured the first necessaries of life, and in this state they remain, and probably forever." Even in the 20th century, these effects could be documented, with reduced beaver populations causing dramatic reductions in the number of ponds on stream courses (Naiman et al. 1988). The paucity of beaver probably also caused an explosion of aspen growth. My observations, over > 30 years, of the same ecosystems in northwestern Ontario suggest that the cropping of aspen by beaver after fire is a key factor allowing the eventual dominance of spruce and pine in boreal landscapes, at least within $50 \mathrm{~m}$ or so of lakes and streams. In brief, the changing habits of indigenous peoples affected aquatic habitats and had important effects on the terrestrial communities in catchments.

Until the late 20th century, some indigenous groups continued to thrive in boreal landscapes, not only living largely on fish and wildlife, but also raising large families with little in the way of modern amenities. For example, I have personally listened to the accounts of several Cree and Chipewyan elders who now live in Fort Chipewyan, Alberta, a community that borders Lake Athabasca and the Peace-Athabasca Delta. They raised families of $12-18$ children in remote parts of the Delta in the 1950s and 1960s, often with only rare contact with "outside." They subsisted on fish, waterfowl, and mammals from the delta, with cash for boats, outboard motors, European clothing, and food supplied by trapping, chiefly for muskrat. Below, I will describe why I have written this in the past tense. It was a healthy lifestyle: many of these people are still active in their mid-80s.

Indigenous people were well adapted to natural variation: the simple fact that they survived and thrived as a species through millenia of rather extreme climatic conditions and their ecological consequences without modern technology is proof. Most tribes were also decimated by European disease such as smallpox, influenza, measles, scarlet fever, and tuberculosis in the 18th, 19th, and early 20th century (e.g., David Thompson's journals in Hopwood 1971, and Flett et al. 1996). They survived these epidemics, despite little assistance from western medicine until the mid-20th century. Whether through lack of technological tools or lack of cultural arrogance, aboriginal peoples in earlier centuries did not apply the extreme, multiple stresses to boreal landscapes that we do today.

\section{MODERN BOREAL MANAGEMENT AND ECOLOGICAL VARIABILITY}

Modern man's management of boreal ecosystems has been pathetic, especially when one considers that fewer than 20 million people live in all of the earth's boreal regions. Forests that have maintained themselves for many millennia without substantial change, both before and during occupation by indigenous people, have been decimated by modern man in little more than 50 years. This is largely due to man's inflated opinions as to the degree to which he understands or can manage such systems. Attempts to replant desirable species after cutting have often failed, perhaps because little attention has been paid to the importance of successional stages. Large areas of single species have allowed insect pests to thrive and spread. Modern management plans seldom account for the caprices of nature, instead assuming that they can be controlled or ameliorated. In particular, adaptation of cutting regimes to fire frequencies has seldom been done. Rowe (1997) has termed the terrestrial result in the boreal zone as "forestry mayhem." These impacts, in turn, have affected the freshwaters of the region. The effects often resemble those following fire, with elevated flows, silt loads, and chemical concentrations (Nicolson 1975, Harr and Fredriksen 1988). Together with direct insults to aquatic ecosystems, these indirect effects are causing a "freshwater mayhem" equal to that described by Rowe for boreal forests. In what follows, I briefly outline several of the major threats to "sustainability" of boreal freshwaters, either directly or via modifications of their catchments.

\section{FISHERIES MANAGEMENT}

Fisheries "management" has not prevented the decline of most carnivorous fish species in boreal regions. Stocking with non-native species, which was considered as good "management" or "enhancement" in the first 70 years of the 20th century, has compromised the ecological integrity of many lakes and streams in the southern part of the boreal region. Due to the sporadic recruitment and slow growth of fishes in boreal waters, recovery of fish populations from severe human perturbations can take several years (Healey 1978, 1980, Schindler et al. 1993).

Anecdotal evidence indicates that fish are decreasing in accessible parts of the boreal region. Lakes in northern Minnesota where I experienced excellent fishing as a boy over 40 years ago are now nearly devoid of fish, according to friends who have fished these systems, some for 50 or more years. Fishermen from more southerly 
locales who used to frequent fishing camps in Minnesota now come to Canada, to the delight of Canadian resort owners. But exploitation is also depleting Canadian fish stocks. Daily limits of lake trout in northwestern Ontario have decreased from 12 fish to 1-2 in the 30 years that I have worked there. Even remote lakes that were seldom visited in the 1960s and 1970s are now fished, as a result of rapidly increasing access by ATV, snowmobile, four-wheel drive automobiles, and aircraft. Some lakes have rather fragile fish populations that can be damaged by even light fishing pressure: for example, lake trout lakes $<50$ ha in area often contain $<300$ lake trout (K. Mills, Freshwater Institute, personal communication). The catch per unit effort of most popular predatory species in Alberta (walleye, bull trout, lake trout, northern pike) is reportedly declining. Similar problems are reported for anadromous stocks with spawning grounds in boreal regions of British Columbia. Tragically, few cases of declines have been well documented in the scientific literature (but see Ryerson and Sullivan 1998). In some areas, fisheries are sustained by stocking from hatcheries, or introductions of non-native species into previously-fishless waters or waters that have become too polluted for native species. If gene pools are considered, however, sustainable fisheries appear to be declining in all but the most remote boreal waters. In many cases, fisheries are not restorable, as the result of damage to fish habitats from other human activities.

Remaining fish stocks are contaminated, often to high concentrations, with PCBs, pesticides, dioxins, and mercury. The fishing guide to Ontario contains advice on contaminants and the edibility of sport fish from most of the larger lakes in the southern part of the province. Most boreal states of the United States have state-wide consumption advisories for fish, as the reult of high and increasing mercury concentrations. This is also true of the Eurasian boreal region. Often, the contaminants originate in nonboreal regions and are carried by long-range transport in the atmosphere. For example, Håkanson et al. (1990) estimate that most of the pike lakes in Sweden that have been "black listed" because of high mercury have become that way because of mercury emissions from coal-fired power plants, both in Sweden and in central Europe. Lake trout in Lake Laberge, at the northern edge of the boreal zone in the Yukon, contain toxaphene concentrations high enough to require recommended limits for human consumption. PCBs, DDT, and mercury are also high, as the result of biomagnification in an unusually long food chain (Kidd et al. 1995a,b). Native people throughout northern Canada contain moderate to high concentrations of mercury, largely as the result of eating large quantities of fish (Wheatley and Paradis 1995).

Also contributing to the decline of fisheries is the destruction of habitat. Many accessible boreal lakes have become ringed with summer cottages. Typically, cottagers remove weeds, logs, and other "structure" from their beach areas, not realizing that these are critical habitat for many fish species. Recently, scientists at ELA have shown that removal of macrophyte beds causes reductions in young-of-the-year pike, yellow perch, and pumpkinseed.

Christensen et al. (1996) found a linear relationship between logs in littoral areas of northern Wisconsin lakes and fish abundance.In many cases, water levels are controlled by dams or weirs at lake outlets, preventing natural fluctuations.

\section{ECOLOGICAL INVASIONS}

Stocking of non-native fish species for angling has compromised the communities of many boreal waters. Whittier et al. (1997) document extreme losses of cyprinid species from lakes of the northeastern United States following introduction of non-native predators, acid precipitation and land-use changes. In central Canada, the catching and dispersal of minnows by commercial bait fishermen has also caused many unrecorded changes to the diversity of boreal waters. Many small lakes are heavily trapped for bait, removing cyprinids of several types. Such species are also moved to fishless lakes by bait fishermen anxious to increase the productivity of their "bait blocks." New species are introduced to habitats where they were not present naturally. Dumping of bait buckets into lakes after fishing trips was an accepted practice until recently, with no thought given as to whether new species were being introduced.

Mysis, crayfish, and leeches have also been moved between habitats. The crayfish species, Orconectes rusticus and $O$. propinquus have slowly invaded boreal habitats once occupied by the native Orconectes virilis as the result of man's activities (DiDonato and Lodge 1993, Hill et al. 1993). Tragically, most of these activities have been unrecorded, and there is probably no way of ascertaining whether or not the biota in a given aquatic system has been altered by human tampering.

There have been other significant effects on boreal freshwaters from the invasion of non-native invertebrates. Most conspicuous are the zebra mussel Dreissena polymorpha and the cladoceran Bythotrephes cederstroemi, both of which are believed to have been originally brought to North America in the bilges of foreign ships entering the Great Lakes. They have subsequently been migrating slowly northward and westward, carried by boats, bait buckets, and other aquatic equipment used in a variety of waters (Hebert et al. 1991, Yan et al. 1992, Ricciardi et al.1997). These organisms have totally restructured the communities upon which fishes depend, displacing and extirpating many native species of invertebrates from southern boreal waters (Yan and Pawson 1997). In addition, the fouling of water intake pipes by zebra mussels has added millions of dollars to the costs of maintaining municipal and industrial water supplies. It is difficult to predict how far they may spread, and methods for their elimination are unknown. 
In freshwater wetlands, purple loosestrife Lythrum salicaria, a native of Europe that was introduced in the late 19th century, is invading eastern and central boreal regions. Originally introduced as an ornamental plant, it rapidly chokes out native vegetation and clogs water flowpaths.

\section{RESERVOIR BUILDING}

Most Canadian hydroelectric reservoirs have been built in the boreal region. Williston Lake on the Peace River, Southern Indian Lake, and the impounded rivers on the eastern side of James Bay are among the larger boreal reservoirs in North America. Together, reservoirs in boreal Canada are equal in area to Lake Ontario (about 20,000 $\mathrm{km}^{2}$ ). Another $11,000 \mathrm{~km}^{2}$ are planned (Rudd et al. 1993). Some of the reservoirs on the Columbia and Fraser Rivers in British Columbia that have destroyed major salmon fisheries lie in boreal landscapes, not in coastal rain forests, as is widely believed.

Most of the large reservoirs have been built for hydroelectric power, once believed to be "good, clean energy" (Bourassa 1985). But several investigations have shown that boreal reservoirs can emit significant quantities of greenhouse gases following the flooding of peat deposits (Rudd et al. 1993, Rosa and Schaeffer 1994, Duchemin et al. 1995, Kelly et al. 1997).

Destruction of beaches and shorelines, spawning habitats, and fisheries by boreal reservoirs are well documented (Bodaly et al. 1984a, $b$ Newbury et al. 1984). In almost every case, raised water levels have caused fishes to become highly contaminated with mercury, frequently exceeding limits for commercial marketing (Rosenberg et al. 1995, Bodaly et al. 1997). We now know that flooded wetlands are the primary source of the mercury, with increased methylation in anoxic regions around decaying vegetation being the mechanism of mobilization (St. Louis et al. 1994, 1996, Kelly et al. 1997).

Many other flow disruptions in southern boreal regions have been small, but numerous. Innocent-appearing roadways and railroads impound wetlands, disrupt stream channels, and impede fish from reaching spawning habitats. Small structures regulate water levels and flows for the purpose of flood control, or, in earlier years, to allow logs to be floated to mills. Many wetlands have been drained, harvested for peat, and cleared for pastures or agriculture. In most areas, there are few regulations to control such activities.

\section{CHANGES TO ABORIGINAL COMMUNITIES: CLEAR EVIDENCE OF NONSUSTAINABLE ACTIVITY}

Large reservoirs, clear-cutting, and oil and mineral exploration have accelerated the demise of native lifestyles in many areas of the boreal zone. The above-mentioned Bennett Dam on the Peace River reduced spring flows to the point at which ice jams no longer occurred on the lower Peace. As a result, spring floods did not rejuvenate the primary successional areas of the Peace-Athabasca Delta adjacent to Lake Athabasca, resulting in enormous declines in populations of fish, waterfowl, and furbearers (Green 1992; see Table 1). As a result, Cree, Chipewyan, and Metis populations deprived of their livelihood no longer live in the Delta as family units. Instead, they live in Fort Chipewyan, where unemployment and poverty are common. Fortunately, no road has yet reached the community, so that the full impact of white civilization has been delayed.

Table 1. Declines in wetland communities and related animals after closing Bennett Dam, summarized from Green (1992)

\begin{tabular}{|c|c|c|}
\hline Losses & $\begin{array}{l}\text { Percentage } \\
\text { Loss }\end{array}$ & Comments \\
\hline \multicolumn{3}{|l|}{$\begin{array}{l}\text { Reduction in } \\
\text { wetlands }\end{array}$} \\
\hline $\begin{array}{l}1967-1989 \\
1967-2006\end{array}$ & $\begin{array}{l}47 \% \\
78 \%\end{array}$ & $\begin{array}{l}\text { Scirpus and other emergents replaced by Calamagrostis, Salix, } \\
\text { other grasses and shrubs }\end{array}$ \\
\hline \multicolumn{3}{|l|}{$\begin{array}{l}\text { Dabbling duck } \\
\text { production }\end{array}$} \\
\hline 1971-1975 & $46 \%$ & Also, reduced fall staging by waterfowl \\
\hline
\end{tabular}




\begin{tabular}{|l||l|l|}
\hline $\begin{array}{l}\text { Diving duck } \\
\text { production } \\
1971-1975\end{array}$ & \\
\hline Muskrat & $46 \%$ \\
\begin{tabular}{l|l}
$1971-1978$ \\
Pre-flood to mid-80s
\end{tabular} & $\begin{array}{l}67 \% \\
95 \%\end{array}$ & $\begin{array}{l}\text { Wetlands dried out } \\
\text { Loss of } \$ 40,000 \text { to } \$ 123,000 \text { annually }\end{array}$ \\
\hline Fish & Decline, magnitude large but unquantified \\
\hline Mink, moose, fox & Declined, magnitude unquantified \\
\hline
\end{tabular}

Until the early 1970s, the Swampy Cree community of Southern Indian Lake in northern Manitoba subsisted on a lucrative commercial fishery for whitefish and walleye. The outflow of the lake was dammed, raising the water level by several meters. The original community is now under water. The commercial fishery has been destroyed by low catches, poor fish quality, and high mercury concentrations (Bodaly et al. 1993). The community was moved to a new location, complete with modern houses and a recreational complex including squash courts. Somehow, squash does not seem to have replaced fishing, trapping, and hunting as a centerpiece for these people's lives. Poverty, depression, and alcohol abuse have resulted. A similar story can be told of the Cree on James Bay, where aboriginal communities are still battling a new phase of hydroelectric development (Rosenberg et al. 1995).

The effect of increased access via logging roads and seismic lines has allowed machine-borne urban hunters to invade traditional hunting, trapping, and fishing grounds upon which aboriginals have relied for centuries.

Competition for game, vandalism, theft of traps, boats, and other equipment, and destruction of trails and drainage patterns are complaints that I hear frequently from many of my aboriginal friends in central and western Canada.

There is also the issue of contamination of native foods. Mercury in most northern native people is high throughout the North. A significant percentage of the population has blood and hair concentrations of mercury approaching the range at which neurological symptoms could occur, although no such effects have yet been documented (Wheatley and Paradis 1995). No studies of fetuses or newborns have been reported. The high values result from eating contaminated fish. Data indicate that most boreal lakes contain 2-5 times the background mercury values, as the result of airborne anthropological emissions, which travel long distances in the atmosphere.

Similarly, PCBs, DDT, toxaphene, and other organochlorine contaminants from remote sources have contaminated arctic foods. Like mercury, these compounds enter in tiny trace amounts, but are biomagnified hundreds of thousands of times as they are passed up food chains to predatory fish (Schindler et al. 1995). PCBs in human breast milk from some aboriginal communities approach levels at which health effects are possible (Dewailly et al. 1989).

Perhaps worst of all, once native people learn that their traditional foods contain foreign contaminants, they cease eating them. There are no ready alternatives in most remote areas, so that there are nutritional and cultural concerns as well as toxicity considerations.

\section{POLLUTANT DISCHARGES}

Despite the remoteness of many boreal regions, industry is taking its toll. Pulp mills, common throughout the boreal regions, once discharged effluents with high BOD and enough dioxins, furans, and other chlorinated compounds to severely contaminate fisheries for many kilometers downstream (e.g., Northern River Basins Study 1996). Many mills had associated chlor-alkali plants, whch produced bleach and sodium hydroxide by elecrolysis, meanwhile leaking hundreds of tons of mercury into boreal lakes and rivers (e.g., Rudd et al. 1983). Bark and chips were also dumped into the rivers, burying spawning and feeding habitats. Fortunately, these problems have recently been recognized, and improved technology now prevents discharges of high BOD or toxic chemicals. However, the problems still exist, due to the persistence of many of the toxins. Some effluents are still toxic, or cause taste and odor problems with downstream waters and fisheries. In many cases, the chemicals causing the problem have not been identified.

Also, the lowered BOD from pulp mills has often come at a price: increased nutrient discharges. Addition of fertilizer to the treatment lagoons of pulp mills has become common practice, for these nutrients limit the breakdown of cellulose and other carbon-rich material. As a result, many pulp mills release as much phosphorus and nitrogen to aquatic systems as a small city would (Northern River Basins Study 1996). This nutrient joins that from the sewage of growing towns and cities, potentially causing eutrophication of boreal waters (Bothwell 1992, Northern River 
Basins Study 1996). Closer regulation of these effluents will be necessary as human populations in the boreal expand.

Other large sources of pollutants are regional. For example, the oil sands of northern Alberta now produce $>40 \%$ of Canada's oil. Oil-rich "tars" are mined in open-pit mines adjacent to the Athabasca River. One accidental discharge from these activities in the 1980 s caused the closure of the commercial fishery on Lake Athabasca, about $250 \mathrm{~km}$ downstream, for three years.

Due to the rapid depletion of conventional oil reserves, the oil sands are expanding rapidly, with a projected expenditure of $>25$ billion dollars (Canadian) in the next decade or so! At present, there are only two large mining projects, but by 2007 , nine or 10 projects are expected to be in operation.

Recently, it was discovered that loons in eastern Canada contain high mercury levels as a result of eating contaminated fish. Concentrations are up to 10 times greater than in western boreal Canada. Behavioral abnormalities have been noted in nesting pairs from Nova Scotia (N. Burgess, Canadian Wildlife Service, unpublished data). Other fish-eating birds and mammals also contain high mercury in the area. The main source of contamination is airborne emissions of mercury, both in the region and in the U.S. Midwest.

\section{HUMAN ACTIVITIES IN CATCHMENTS}

Human activity in catchments alters both seasonal and long-term variation in hydrology and chemistry of lakes and streams, as well as average flows and chemical conditions. In addition to widespread clear-cut logging and flooding, fire suppression, prescribed fires, and land clearing for agriculture or recreational housing are common in the boreal region.

Some of our past "understanding" seems crazy today. For example, in the early 1970s, there was great concern that human fire suppression was so effective that fire-dependent species such as jackpine were threatened (see, for example, papers in Quaternary Research, Volume 3,1973). However, since then, climate has warmed slightly, enough to greatly increase fire in the boreal zone. Despite continued technological improvements, the annual area burned since the early 1970s has nearly doubled (Kurz et al. 1995). Today, one seldom hears scientists concerned about the extirpation of boreal species by fire suppression, except in national parks.

Clear-cut logging appears to affect stream chemistry in ways that are analogous to fire in most respects. In general, two- to threefold increases in water flows, silt, and chemical inputs are observed following cutting, with most effects disappearing within 2-3 years (Nicolson 1975). However, in flatter areas such as northern Alberta and Minnesota, clear-cutting can cause higher water levels in wetlands, due largely to decreased evapotranspiration (Verry 1986).

Destruction of riparian areas can lead to increased nutrient inputs, increased stream temperatures, and increased exposure of stream organisms to UV radiation (Ryan and Grant 1991; D. Kelly and J. Clare, University of Alberta, unpublished data).

A more important effect of logging on boreal aquatic systems is the building of logging roads. In addition to the access problem previously described, such roads impound wetlands, interrupt streamflows, prevent fish passage and beaver activity, and cause erosion and siltation (Mattice 1977).

Other activities also affect wetlands. In Canada, a total of $20 \times 10^{6}$ ha have been altered for other uses. Over 900,000 ha have been flooded for hydroelectric reservoirs or degraded as the result of hydroelectric projects. Proposed reservoir projects could consume an additional $1 \times 10^{6}$ ha (Urquiizo et al. 1998). Market gardening, horticultural harvesting of peat, conversion to forest production, and harvesting of peat for energy have affected another 50,000 ha. Much of the harvested peat is exported. Urquizo et al. (1998) provide more detail.

\section{HUMAN ALTERATIONS TO THE ATMOSPHERE THAT AFFECT THE BOREAL REGION}

The general problems of climate warming, acid precipitation, and increasing UV radiation resulting from stratospheric ozone depletion are widely known, but detailed effects are not widely studied. The boreal region is among those most sensitive to all three perturbations.

\section{Acid precipitation}

The effects of acid precipitation on boreal waters are well known. Large areas of the boreal zone are found on the Precambrian Shield or other hard-rock geology, which weathers only slowly. As a result, many boreal waters have 
low alkalinities that render them very susceptible to acidification.

Effects on sensitive species and chemical cycles are known to begin as pH values decrease below 6.0 (Schindler et al. 1985a, 1991). By the time lakes are acidified to $\mathrm{pH} 5$, major reductions in biodiversity occur, with near-complete elimination of fishes, molluscs, and crustaceans, and severely depleted species assemblages in other taxonomic groups (Schindler et al. 1985a, 1989). In eastern Canada, thousands of lakes have been moderately affected and hundreds of thousands of lake populations have been eliminated (Minns et al. 1990, 1992). Lakes in large boreal regions of Norway, Sweden, and the Soviet Union, and small regions of the United States have suffered to some degree from acidification.

In Europe, new threats from acidification are now posed by increasing emissions of oxides of nitrogen and ammonium to the atmosphere (Henriksen and Brakke 1988, Schuurkes and Mosello 1988). Nitrogen was once believed to play an insignificant role in acidification, because it was assumed that terrestrial ecosystems would remove the excess nitrogen. However, we now know that forests can become saturated with nitrogen, leading to the escape of nitric acid to downstream waters. Although denitrification can remove some of the nitrate reaching aquatic ecosystems, nitric acid can acidify with almost the same efficiency as sulfuric acid (Rudd et al. 1988). Ammonium acidifies when plants take up ammonia, leaving hydrogen ions behind (Schindler et al. 1985b, Schuurkes and Mosello 1988). Although such problems are not yet widespread in North America, they are already emerging in some areas (Kelly et al. 1990, Jeffries 1995), and we must act quickly to prevent them.

In North America, despite the destruction documented from eastern boreal regions, western development is threatening to increase acid precipitation. Sulfate deposition in the previously mentioned tar sands area of Alberta already approaches the critical loads for boreal areas of Europe and the East (Schindler 1996b). Although expansion plans project that sulfur emissions in the region will remain constant, nitrogen oxide emissions will increase sharply as a result of greatly increased use of large trucks and other equipment in mining operations. Together, the companies expanding in the area are predicted to emit $>200 \mathrm{Mg}$ of $\mathrm{NO}_{\mathrm{x}} / \mathrm{d}$ (Syncrude Canada 1998).

\section{Climate warming}

Climatic warming causes declines in chemical and hydrological inputs to lakes and streams; unless there are large increases in precipitation, increased evapotranspiration will dominate the hydrological cycle (Schindler 1997).

Lakes increase in transparency as the result of lower inputs of dissolved organic carbon (DOC), causing increased depth of euphotic zones, increased thermocline depths, and probably increased success of sight-dependent predators (Schindler et al. 1996a). In addition, the deeper thermoclines cause reduced habitat for cold stenothermic organisms in summer hypolimnions. Typically, such organisms are also intolerant of low oxygen (Schindler et al. 1996a). Water renewal times of lakes increase, causing increased concentrations of chemicals, increased importance of in-lake processes (for example, sulfate reduction, diffusion of nutrients and base cations from sediments), and increased eutrophication (Dillon and Rigler 1975, Vollenweider 1976, Schindler et al. 1978).

Climate warming also exacerbates acidification or delays the recovery of lakes and streams after acidifying emissions have been reduced. In general, reoxidation of reduced sulfur in wetlands, wet soils, and littoral areas of lakes is responsible for acidification (Bayley et al. 1992a,b, Lazerte 1993, Schindler et al. 1996b Yan et al. 1996).

There are also indirect effects. For example, forest fires increase the exposure of lakes to wind, causing effects on thermal stratification (Schindler et al. 1990). Like clear-cut logging, increased UV exposure and temperature are expected in streams. Sedimentation also increases (Beaty 1994).

\section{Stratospheric ozone depletion}

Stratospheric ozone has been somewhat depleted over much of the boreal zone. As a result, UV-b radiation has increased by several percentage points a year in the late 1980s and early 1990s (Kerr and McElroy 1993). However, other human activities may increase UV exposure more than does ozone depletion.

For example, the colored dissolved organic matter that enters boreal lakes and streams from wetlands and wet soils (commonly called DOC, or dissolved organic carbon, for it is customary to quantify it by its carbon content) is the major attenuator of all wavelengths of solar radiation in most boreal lakes. It effectively provides a UV "shield" for aquatic ecosystems. DOC decreases as the result of both climatic warming and acidification. In the case of climate warming, increased evapotranspiration causes streamflow to decrease, so that less colored DOC is transpored to lakes (Schindler et al. 1996a). In lakes, warmer temperatures, longer ice-free seasons, and clearer waters cause increased rates of bleaching and degradation of colored DOC (Dillon and Molot 1997, Schindler et al. 1997). Acidification causes rapid disappearance of DOC as the result of precipitation and enhanced

photodegradation (Jones et al. 1986, Molot and Dillon 1996). .As a result, UV penetrates farther into freshwaters that have been affected by climatic warming and acidification. The relationship is a negative exponential, so that effects are particularly acute in lakes where DOC is low. In general, boreal lakes with $<300 \mathrm{micromol} / \mathrm{L}$ DOC are very vulnerable to UV as a result of DOC decreases (Schindler et al. 1996b, Yan et al. 1996). About 20\% of the 
lakes in Ontario would fall into this DOC range. This combined effect of climatic warming, acidification, and increasing UV has been termed a "three-pronged attack" on boreal lakes by Gorham (1996).

\section{BUILDING A SUSTAINABLE ECONOMY IN BOREAL REGIONS}

Clearly, long-term sustainability of boreal ecosystems will require both lower rates of exploitation and management strategies that are flexible enough to adapt to natural variation. For example, exploitation of fisheries could be increased for strong year classes and reduced for weak ones. Similarly, forest harvesting strategies must account for changing incidence of fire, which is generally predictable (older or damaged forests are more susceptible to fire; drier conditions promote fire), but not with short-term precision (the years in which the critical combination of fire weather and sufficient fuel are available cannot be predicted in advance). At present, our management strategies make little attempt to adapt to this variability.

In order to thrive, human populations in the boreal zone must remain low, perhaps even lower than they are now. Productivity of boreal systems is low, and the diversity of ecologically sustainable occupations available to humans is limited. In particular, maintenance of traditional aboriginal lifestyles and cultures depends on protecting access to large tracts of boreal landscape, kept in near-pristine conditions. This must be given high priority for the immediate future: development that destroys cultures is, by its very definition, not sustainable.

Even in small communities, it is important to promote a diversity of economic activities. One-industry towns are still common in boreal regions. Dependence on one forestry company, one mine, or tourism (often as fishermen or hunters) lends truth to the popular lyric "I owe my soul to the company store." Repeatedly, such towns have been made, and then broken, based on the fortunes of single industries, whether the fortunes be driven by fire weather or the stock market. A diversity of human enterprise seems to me to be fundamental to a sustainable human economy, for all industries are unlikely to either peak or "crash" simultaneously. As electronic communications improve, human populations in boreal areas and the wealth of communities may increase without the need for local, resource-exploiting jobs, similar to the changes already underway in attractive regions of the American West. However, such populations still require space for recreation, housing, and other infrastructure. So far, no equivalent wave of immigration has hit the Boreal, probably because of the cold climate in much of the region. I predict that it will begin early in the new millenium, as people seek to escape the crowding, pollution, and crime of large urban areas. As in the West, these new immigrants will change the entire character of small, human communities in the boreal region.

Rather than relying on a single megaproject, a healthy and sustainable boreal town might depend on a number of smaller, more diverse activities, perhaps small sawmills, outfitting for hunting, fishing, canoeing, boating, and other outdoor activities, and some computer-based employment as the basis for its economy, with perhaps an occasional small pulp mill or mine. Such a diverse mix is very rare. One only has to drive across northern Ontario through a succession of declining mill or mining towns, one-company towns, to recognize that most are presently far from sustainable.

Exacerbating the problem in one-industry towns is the rapid tendency for forestry and mining companies to expand and mechanize, eliminating jobs while cutting forests at increasing rates. The ratio of mayhem to boreal resident has increased severalfold in a few decades. Of course, unemployment is a concern of politicians, so the solution has always been to expand forestry, mining, and other extraction of resources. In Canada, most recent expansions have been by very large, nonresident, multinational corporations with little real interest in sustaining the Boreal or its residents. Sometimes it is puzzling why companies invest in machines rather than humans. I have seen robots in pulp and paper mills moving rolls of paper or bales of pulp that a man with a simple cart or lever could move as efficiently, at lower cost. One key to sustainability appears to be to convince or require companies to invest in people, rather than mechanization, and for universities and industries to focus on designing machines that make it easier for individuals to do meaningful work, rather than machines to replace them. Unfortunately, this is not the modern way.

Some of the necessary changes to make boreal waters sustainable can be made locally. These include:

1) Immediate implementation of catch and release fishing policies.

2) More restrictions on the disruption of drainage patterns by roads and railways.

3) Discouragement of additional cottage development.

4) Severe restrictions on access.

5) More stringent reductions on sulfur oxide and nitrogen oxide emissions.

6) Greatly reduced forest cutting. 
7) Termination of live-bait fisheries.

8) Further improvements to pulp mill effluents, with a long-term objective of no discharge to watercourses.

9) Restrictions on human populations in the Boreal.

10) No disruptions to natural flow patterns.

11) Elimination of local sources of mercury and other contaminants.

12) Protection of riparian areas.

13) Stringent management of nutrient inputs.

However, many of the changes needed to protect the boreal region must be made elsewhere. For example, the acid rain, stratospheric ozone depletion, climate warming, mercury, and organochlorine problems previously described are largely the result of human activities in far away places. Clearly, it is important to bring international attention to the problems that these activities are causing to boreal ecosystems and peoples.

In summary, I am sorry to present such a depressing view of the future of boreal landscapes, with resulting changes to boreal lakes and streams. But the view is simply an extension of what I have personally seen happen in the past three decades, and policies in Canada, the United States, and other boreal countries are accelerating, not preventing further destruction. Unless this is changed rapidly, within 50 years, all but the most remote northern regions of the boreal zone will have followed the course of the long-grass prairie: all that will be left will be a few small parks, probably of insufficient size to sustain far-ranging boreal species such as woodland caribou, lynx, fisher, and wolverine. Cougars and grizzlies, always rare, will become extinct in boreal regions. No fishing for lake trout will be allowed, as the result of contaminant burdens and population declines from habitat destruction and overexploitation. The call of loons, the chatter of kingfishers, the melodious notes of migratory song birds will be much rarer. Drinking directly from boreal lakes and streams, as I have done for my entire life, will be a thing of the past.

\section{RESPONSES TO THIS ARTICLE}

Responses to this article are invited. If accepted for publication, your response will be hyperlinked to the article. To submit a comment, follow this link. To read comments already accepted, follow this link.

\section{Acknowledgments:}

I am grateful to Elders Mary Waquan, Madeline Marcel, Josephine Mercrede, Victoria Mercrede, and Daniel Marcel of the Fort Chipewyan First Nations for their descriptions of life on the land in the Peace-Athabasca Delta before the closure of Bennett Dam. John Pastor and an anonymous referee provided excellent critiques of an earlier draft. John Gunn, Ken Mills, Brian Parker, and Daniel Schindler provided references for some of the fisheries issues.

\section{LITERATURE CITED}

Bayley, S. E., R. S. Behr, and C. A. Kelly. 1986. Retention and release of S from a freshwater wetland. Water, Air, and Soil Pollution 31: 101-114.

Bayley, S. E., D. W. Schindler, K. G. Beaty, B. R. Parker, and M. P. Stainton. 1992a. Effects of multiple fires on nutrient yields from streams draining boreal forest and fen watersheds: nitrogen and phosphorus. Canadian Journal of Fisheries and Aquatic Sciences 49(3): 584-596.

Bayley, S. E., D. W. Schindler, B. R. Parker, M. P. Stainton, and K. G. Beaty. 1992b. Effect of forest fire and drought on acidity of a base-poor boreal forest stream: similarities between climatic warming and acidic precipitation. Biogeochemistry 17: 191-204.

Beaty, K. G. 1994. Sediment transport in a small stream following two successive forest fires. Canadian Journal of Fisheries and Aquatic Sciences 51: 2723-2733.

Bilyj, B., and I. J. Davies. 1989. Descriptions and ecological notes on seven new species of Cladotanytarsus (Chironomidae: Diptera) collected from an experimentally acidified lake. Canadian Journal of Zoology 67: 948-962.

Bodaly, R. A., R. E. Hecky, and R. J. P. Fudge. 1984a. Increases in fish mercury levels in lakes flooded by the 
Churchill River diversion, northern Manitoba. Canadian Journal of Fisheries and Aquatic Sciences 41: 682-691.

Bodaly, R. A., T. W. D. Johnson, R. J. P. Fudge, and J. W. Clayton. 1984b. Collapse of the lake whitefish (Coregonus clupeaformis) fishery in southern Indian Lake, Manitoba, following lake impoundment and river diversion. Canadian Journal of Fisheries and Aquatic Sciences 41: 692-700.

Bodaly, R. A., J. W. M. Rudd, R. J. P. Fudge, and C. A. Kelly. 1993. Mercury concentrations in fish related to size of remote Canadian Shield lakes. Canadian Journal of Fisheries and Aquatic Sciences 50: 980-987.

Bodaly, R. A., V. L. St. Louis, M. J. Paterson, R. J. P. Fudge, B. D. Hall, D. M. Rosenberg, and J. W. M. Rudd. 1997. Bioaccumulation of mercury in the aquatic food chain in newly flooded areas. Pages 259-287 in $\mathrm{H}$. Segel and A. Sigel, editors. Mercury and its effects on environment and biology. Marcel Dekker, New York, New York, USA.

Bothwell, M. L. 1992. Eutrophication of rivers by nutrients in treated kraft pulp mill effluent. Water Pollution Research Journal of Canada 27: 447-472.

Bourassa, R. 1985. Power from the North. Prentice-Hall Canada, Scarborough, Ontario, Canada.

Christensen, D. L., B. R. Herwig, D. E. Schindler, and S. R. Carpenter. 1996. Impacts of lakeshore residential development on coarse woody debris in north temperate lakes. Ecological Applications 6: 1143-1149.

Colby. P. J., and L. T. Brooke. 1969. Cisco (Coregonus artedii) mortalities in a southern Michigan lake, July 1968. Limnology and Oceanography 14: 958-960.

Coues, E. 1897. The manuscript journals of Alexander Henry and of David Thompson. Ross and Haines, Minneapolis, Minnesota, USA.

Curtis, P. J., and D. W. Schindler. 1997. Hydrologic control of dissolved organic matter in low-order Precambrian Shield lakes, northwestern Ontario. Biogeochemistry 36: 125-138.

Dadswell, M. J. 1974. Distribution ecology and postglacial dispersal of certain crustaceans and fishes in eastern North America. National Museum of Natural Sciences, Ottawa, Canada.

Dewailly, E., A. Nantel, J. Weber, and F. Meyer. 1989. High levels of PCBs in breast milk of Inuit women from Arctic Quebec. Bulletin of Environmental Contamination and Toxicology 43: 641-646.

DiDonato, G. T., and D. M. Lodge. 1993. Species replacements among Orconectes crayfishes in Wisconsin lakes: the role of predation by fish. Canadian Journal of Fisheries and Aquatic Sciences 50: 1484-1488.

Dillon, P. J., and L. A. Molot. 1997. Dissolved organic and inorganic carbon mass balances in central Ontario lakes. Biogeochemisry 36: 29-42.

Dillon, P. J., and F. H. Rigler. 1975. A simple method for predicting the capacity of a lake for development based on lake trophic status. Journal of the Fisheries Research Board of Canada 32: 1519-1531.

Duchemin, E., M. Lucotte, R. Canuel, and A. Chamberland. 1995. Production of the greenhouse gases $\mathrm{CH}_{4}$ and $\mathrm{CO}_{2}$ by hydroelectric reservoirs of the boreal region. Global Biogeochemical Cycles 9: 529-540.

Engstrom, D. R. 1987. Influence of vegetation and hydrology on the humus budgets of Labrador lakes. Canadian Journal of Fisheries and Aquatic Sciences 44: 1306-1314.

Fee, E. J., and R. E. Hecky. 1992. Introduction to the Northwest Ontario Lake Size Series (NOLSS). Canadian Journal of Fisheries and Aquatic Sciences 49: 2434-2444.

Fee, E. J., R. E. Hecky, S. E. M. Kasian, and D. R. Cruikshank. 1996. Effects of lake size, water clarity, and climatic variability on mixing depths in Canadian Shield lakes. Limnology and Oceanography 41: 912-920.

Findlay, D. L., and S. E. M. Kasian. 1986. Phytoplankton community responses to acidification of Lake 223, Experimental Lakes Area, northwestern Ontario. Water, Air, and Soil Pollution 30: 719-726.

Findlay, D. L., and S.,E.,M. Kasian. 1987. Phytoplankton community responses to nutrient addition in Lake 226, Experimental Lakes Area, northwestern Ontario. Canadian Journal of Fisheries and Aquatic Sciences $4 \mathbf{4}$ (Supplement 1): 35-46.

Findlay, D. L., and S. E. M. Kasian. 1990. Phytoplankton communities of lakes experimentally acidified with sulfuric and nitric acids. Canadian Journal of Fisheries and Aquatic Sciences 47: 1378-1386. 
Findlay, D. L., and S.,E.,M. Kasian. 1996. The effects of incremental pH recovery on the Lake 223 phytoplankton community. Canadian Journal of Fisheries and Aquatic Sciences 53: 856-864.

Flett, L., L. Bill, J. Crozier, and D. Surrendi. 1996. A report of wisdom synthesized from the traditional knowledge component studies. Northern River Basins Study, Sythesis Report Number 12. Alberta Environmental Protection, Edmonton, Alberta, Canada.

Frost, T. M., S. R. Carpenter, A. R. Ives, and T. K. Kratz. 1995. Species compensation and complementarity in ecosystem function. Pages 224-239 in C. Jones and J. H. Lawton, editors. Linking species and ecosystems. Chapman and Hall, New York, New York, USA.

Gorham, E. 1991. Northern peatlands: role in the carbon cycle and probable responses to climatic warming. Ecological Applications 1: 182-195. . 1996. Lakes under a three-pronged attack. Nature 381: 109-110.

Green, J. R. 1992. A preliminary assessment of the effects of W. C. Bennett Dam on the Athabasca River Delta and the Athabasca Chipewyan Band. Athabasca Chipewyan Band, Fort Chipewyan, Alberta, Canada.

Håkanson, L., T. Andersson, and A. Nilsson. 1990. Mercury in fish in Swedish lakes - linkages to domestic and European sources of emission. Water, Air, and Soil Pollution 50: 171-191.

Harr, R. D., and R. L. Fredriksen. 1988. Water quality after logging small watersheds within the Bull Run Watershed, Oregon. Water Resources Bulletin 24: 1103-1111.

Healey, M. C. 1978. The dynamics of exploited lake trout populations and implications for management. Journal of Wildlife Management 42: 307-328.

. 1980. Growth and recruitment in experimentally exploited lake whitefish (Coregonus clupeaformis) populations. Canadian Journal of Fisheries and Aquatic Sciences 37: 255-267.

Hebert, P. D. N., C. C. Wilson, M. H. Murdoch, and R. Lazar. 1991. Demography and ecological impacts of the invading mollusc Dreissena polymorpha. Canadian Journal of Zoology 69: 405-409.

Heinselman, M. L. 1973. Fire in the virgin forests of the Boundary Waters Canoe Area, Minnesota. Quaternary Research 3: 329-382.

Henriksen, A., and D. F. Brakke. 1988. Increasing contributions of nitrogen to the acidity of surface waters in Norway. Water, Air, and Soil Pollution 42: 183-201.

Hill, A. M., D. M. Simars, and D. M. Lodge. 1993. Invasion of an occupied niche by the crayfish Orconectes rusticus: potential importance of growth and mortality. Oecologia 94: 303-306.

Hopwood, V. G., editor. 1971. Travels in Western North America, by David Thompson. Macmillan of Canada, Toronto, Canada.

Howarth, R. W., editor. 1996. Nitrogen cycling in the North Atlantic and its watersheds. Kluwer Academic, Boston, Massachusetts, USA.

Imberger, J. 1994. Transport processes in lakes: a review. Pages 99-193 in R. Margalef, editor. Limnology now: a paradigm of planetary problems. Elsevier Science.

Jeffries, D. S. 1995. Fresh water acidification in Canada caused by atmospheric deposition of nitrogen pollutants: a preliminary assessment of existing information. A draft discussion paper. NWRI (National Water Research Institute) Contribution 95-116, Burlington, Ontario, Canada.

Jones, M. L., D. R. Marmorek, B. S. Reuber, P. J. McNamee, and L. P. Rattie. 1986. "Brown waters": relative importance of external and internal sources of acidification on catchment biota. LRTAP (Long-Range Transport of Atmospheric Pollutants) Workshop Number 5. ESSA (Environmental and Social Systems Analysts), Toronto, Canada.

Kay, C. E. 1994. Aboriginal overkill: the role of native Americans in structuring western ecosystems. Human Nature 5: 359-398.

Kelly, C. A., J. W. M. Rudd, and D. W. Schindler. 1990. Acidification by nitric acid - future considerations. Water, Air, and Soil Pollution. 50: 49-61.

Kelly, C. A., J. W. M. Rudd, R. A. Bodaly, N. T. Roulet, V. L. StLouis, A. Heyes, T. R. Moore, S. Schiff, R. 
Aravena, K. J. Scott, B. Dyck, R. Harris, B. Warner, and G. Edwards. 1997. Increases in fluxes of greenhouse gases and methyl mercury following flooding of an experimental reservoir. Environmental Science and Technology 31: 1334-1344.

Kerr, J. B., and C. T. McElroy. 1993. Evidence of large upward trends of ultraviolet-B radiation linked to ozone depletion. Science 262: 1032-1034.

Kidd, K. A., R. H. Hesslein, R. J. P. Fudge, and K. A. Hallard. 1995b. The influence of trophic level as measured by ${ }^{15} \mathrm{~N}$ on mercury concentrations in freshwater organisms. Water, Air, and Soil Pollution $\mathbf{8 0}$ : 1011-1015.

Kidd, K. A., D. W. Schindler, D. C. G. Muir, W. L. Lockhart, and R. H. Hesslein. 1995a. High toxaphene concentrations in fish from a subarctic lake. Science 269: 240-242.

Kurz, W. A., M. J. Apps, S. J. Beukemia, and T. Lekstrum. 1995. 20th century carbon budget of Canadian forests. Tellus 47B: 170-177.

Lazerte, B. D. 1993. The impact of drought and acidification on the chemical exports from a minerotrophic conifer swamp. Biogeochemistry 18: 153-175.

Lewis, H. T. 1977. Maskuta: the ecology of Indian fires in northern Alberta. Western Journal of Anthropology 7: 15-52.

Lewis, H. T., and T. A. Ferguson. 1988. Yards, corridors and mosaics: how to burn a boreal forest. Human Ecology 16: 57-77.

Malley, D. F., D. L. Findlay, and P. S. S. Chang. 1982. Ecological effects of acid precipitation on zooplankton. Pages 297-327 in F. M. D'Itri, editor. Acid precipitation: effects on ecological systems. Ann Arbor Science Publishers, Ann Arbor, Michigan, USA.

Mattice, C. R. 1977. Forest road erosion in northern Ontario: Aa preliminary analysis. Canadian Forestry Service, Department of Fisheries and the Environment Report 0-X-254, Sault St. Marie, Ontario, Canada.

Mills, K. H., and S. M. Chalanchuk. 1988. Population dynamics of unexploited lake whitefish (Coregonus clupeaformis) in one experimentally fertilized lake and three exploited lakes. Finnish Fisheries Research 9: 145-153.

Minns, C. K., J. E. Moore, D. W. Schindler, P. G. C. Campbell, P. J. Dillon, J. K. Underwood, and D. M. Whelpdale. 1992. Expected reduction in damage to Canadian lakes under legislated and proposed decreases in sulphur dioxide emissions. Report 92-1, Committee on Acid Deposition, Royal Society of Canada. Ottawa, Canada. pp.

Minns, C. K., J. E. Moore, D. W. Schindler, and M. L. Jones. 1990. Assessing the potential extent of danger to inland lakes in eastern Canada due to acidic deposition. III. Predicted impacts on species richness in seven groups of aquatic biota. Canadian Journal of Fisheries and Aquatic Sciences 47: 821-830.

Molot, L., and P. J. Dillon. 1996. Storage of terrestrial carbon in boreal lake sediments and evasion to the atmosphere. Global Biogeochemical Cycles 10: 483-492.

Naiman, R. J., C. A. Johnston, and J. C. Kelley. 1988. Alteration of North American streams by beaver: the structure and dynamics of streams are changing as beaver recolonize their historic habitat. BioScience $\mathbf{3 8}$ : 753-762.

Newbury, R. W., G. K. McCullough, and R. E. Hecky. 1984. The Southern Indian Lake impoundment and Churchill River Diversion. Canadian Journal of Fisheries and Aquatic Sciences 41: 548-557.

Newman, P. C. 1987. Caesars of the wilderness. Viking, Markham, Ontario, Canada.

Nicolson, J. A. 1975. Water quality and clearcutting in a boreal forest ecosystem. Proceedings of Canadian Hydrology Symposium-75: 734-738. NRCC Number 15195, 11-14 August, Winnipeg, Manitoba, Canada.

Northern River Basins Study. 1996. Final Report to the Ministers. Alberta Environmental Protection, Edmonton, Alberta, Canada.

Payette, S., C. Morneau, L. Sirois, and M. Desponts. 1989. Recent fire history of the northern Québec biomes. Ecology 70: 656-673.

Rasmussen, J. B., L. Godbout, and M. Shallenberg. 1989. The humic content of lake water and its relationship 
to watershed and lake morphometry. Limnology and Oceanography 34: 1336-1343.

Ricciardi, A., J. G. Whoriskey, and J. B. Rasmussen. 1997. The role of the zebra mussel (Dreissena polymorpha) in structuring macroinvertebrate communities on hard substrata. Canadian Journal of Fisheries and Aquatic Sciences 54: 3596-2608.

Ritchie, J. C., and G. A. Yarranton. 1978. The Late-Quaternary history of the boreal forest of central Canada, based on standard pollen stratigraphy and principal components analysis. Journal of Ecology 66: 199-212.

Robinson, H. M. 1879. The great fur land. G. P. Putnam's Sons, New York, New York, USA.

Rochefort, L., D. H. Vitt, and S. E. Bayley. 1990. Growth, production, and decomposition dynamics of Sphagnum under natural and experimentally acidified conditions. Ecology 71: 1986-2000.

Rosa, L. P., and R. Schaeffer. 1994. Greenhouse gas emissions from hydroelectric reservoirs. Ambio 23: 164-165.

Rosenberg, D. M., R. A. Bodaly, and P. J. Usher. 1995. Environmental and social impacts of large-scale hydroelectric development: who is listening? Global Environmental Change 5: 127-148.

Rowe, J. S. 1997. Boreal forest in the global context. Natural Science 1: 1-3.

Rudd, J. W. M., R. Harris, C. A. Kelly, and R. E. Hecky. 1993. Are hydroelectric reservoirs significant sources of greenhouse gases? Ambio 22: 246-248.

Rudd, J. W. M., C. A. Kelly, D. W. Schindler, and M. A. Turner. 1988. Disruption of the nitrogen cycle in acidified lakes. Science 240: 1515-1517.

Rudd, J. W. M., M. A. Turner, A. Furutani, A. L. Swick, and B. E. Townsend. 1983. The English-Wabigoon River system: I. A synthesis of recent research with a view towards mercury amelioration. Canadian Journal of Fisheries and Aquatic Sciences 40: 2206-2217.

Rudstam, L. G., and J. J. Magnuson. 1985. Predicting the vertical distribution of fish populations: analysis of cisco, Coregonus artedii, and yellow perch, Perca flavescens. Canadian Journal of Fisheries and Aquatic Sciences 42: $1178-1188$.

Ryan, S. E., and G. E. Grant. 1991. Downstream effects of timber harvesting on channel morphology in Elk River Basin, Oregon. Journal of Environmental Quality 20: 60-72.

Ryerson, D., and M. Sullivan. 1998. Where have all the northern pike gone? Alberta Naturalist 28: 12-13.

Schindler, D. W. 1971. A hypothesis to explain differences and similarities among lakes in the Experimental Lakes Area (ELA), northwestern Ontario. Journal of the Fisheries Research Board of Canada 28: 295-301.

. 1988a. Effects of acid rain on freshwater ecosystems. Science 239: 149-157.

. 1988b. Experimental studies of chemical stressors on whole-lake ecosystems. Baldi Lecture.

Verhandlungen der Internationalen Vereinigung fuer Theoretische und Angewandte Limnologie 23: 11-41.

. 1990a.in G. Woodwell, editor. The Earth in transition: patterns and processes of biotic impoverishment. Cambridge University Press, Cambridge, UK.

. 1990b. Experimental perturbations of whole lakes as tests of hypotheses concerning ecosystem structure and function. Proceedings of the 1987 Crafoord Symposium. Oikos 57: 25-41.

- 1996a. Ecosystems and ecotoxicology: a personal perspective. Pages 371-398 in M. C. Newman and C. H. Jagoe, editors. Aquatic toxicology: a hierarchical treatment. Lewis Publishers, Boca Raton, Florida, USA.

-1996b. The response of aquatic ecosystems in Alberta to acidifying deposition. Section 2 of the Scientific Appendix to the Final Report of the Target Loading Subgroup on Critical and Target Loading in Alberta. Clean Air Strategic Alliance, Edmonton, Alberta, Canada.

$\overline{1043-1067}$

. 1997. Widespread effects of climatic warming on freshwater ecosystems. Hydrologic Processes 11 :

. 1998. A dim future for boreal waters and landscapes: cumulative effects of climatic warming, stratospheric ozone depletion, acid precipitation, and other human activities. BioScience 48: 157-164.

Schindler, D. W., S. E. Bayley, B. R. Parker, K. G. Beaty, D. R. Cruikshank, E. J. Fee, E. U. Schindler, and 
M. P. Stainton. 1996a. The effects of climatic warming on the properties of boreal lakes and streams at the Experimental Lakes Area, Northwestern Ontario. Limnology and Oceanography 41: 1004-1017.

Schindler, D. W., K. G. Beaty, E. J. Fee, D. R. Cruikshank, E. D. DeBruyn, D. L. Findlay, G. A. Linsey, J. A. Shearer, M. P. Stainton, and M. A. Turner. 1990. Effects of climatic warming on lakes of the central boreal forest. Science 250: 967-970.

Schindler, D. W., P. J. Curtis, S. E. Bayley, B. R. Parker, K. G. Beaty, and M. P. Stainton. 1997. Climateinduced changes in the dissolved organic carbon budgets of boreal lakes. Biogeochemistry 36: 9-28.

Schindler, D. W., P. J. Curtis, B. Parker, and M. P. Stainton. 1996b. Consequences of climate warming and lake acidification for UV-b penetration in North American boreal lakes. Nature 379: 705-708.

Schindler, D. W., E. J. Fee, and T. Ruszczynski. 1978. Phosphorus input and its consequences for phytoplankton standing crop and production in the Experimental Lakes Area and in similar lakes. Journal of the Fisheries Research Board of Canada 35: 190-196.

Schindler, D. W., et al. 1991. Comparisons between experimentally-and atmospherically-acidified lakes during stress and recovery. Pages 193-226 in F. T. Last and R. Watling, editors. Acidic deposition: its nature and impacts. Proceedings of the Royal Society of Edinburgh, Volume 97B. Royal Society of Edinburgh, Edinburgh, Scotland.

Schindler, D. W., R. E. Hecky, and K. H. Mills. 1993. Two decades of whole-lake eutrophication and acidification experiments. Pages 294-304 in L. Rasmussen, T. Brydges, and P. Mathy, editors. Experimental manipulations of biota and biogeochemical cycling in ecosystems. Commission of the European Communities, Brussels, Belgium.

Schindler, D. W., S. E. M. Kasian, and R. H. Hesslein. 1989. Losses of biota from American aquatic communities due to acid rain. Proceedings of the World Wildlife Conference, Estes Park, Colorado, 14-18 September 1987. Environmental Monitoring and Assessment 12: 269-285.

Schindler, D. W., K. A. Kidd, D. Muir, and L. Lockhart. 1995. The effects of ecosystem characteristics on contaminant distribution in northern freshwater lakes. Science of the Total Environment 160/161: 1-17.

Schindler, D. W., K. H. Mills, D. F. Malley, D. L. Findlay, J. A. Shearer, I. J. Davies, M. A. Turner, G. A. Linsey, and D. R. Cruikshank. 1985a. Long-term ecosystem stress: the effects of years of experimental acidification on a small lake. Science 228: 1395-1401.

Schindler, D. W., R. W. Newbury, K. G. Beaty, and P. Campbell. 1976. Natural water and chemical budgets for a small Precambrian lake basin in central Canada. Journal of the Fisheries Research Board of Canada 33: 2526-2543.

Schindler, D. W., R. W. Newbury, K. G. Beaty, J. Prokopowich, T. Ruszczynski, and J. A. Dalton. 1980. Effects of a windstorm and forest fire on chemical losses from forested watersheds and on the quality of receiving streams. Canadian Journal of Fisheries and Aquatic Sciences 37: 328-334.

Schindler, D. W., M. A. Turner, and R. H. Hesslein. 1985b. Acidification and alkalinization of lakes by experimental addition of nitrogen compounds. Biogeochemistry 1: 117-133.

Schuurkes, J. A. A. R., and R. Mosello. 1988. The role of external ammonium inputs in freshwater acidification. Schweizerische Zeitschrift fuer Hydrologie 50: 71-86.

Sellers, T. J., B. R. Parker, D. W. Schindler, and WM. Tonn. 1998. The pelagic distribution of lake trout (Salvelinus namaycush) in small Canadian Shield lakes with respect to temperature, dissolved oxygen, and light. Canadian Journal of Fisheries and Aquatic Sciences 55: 170-179.

St. Louis, V. L., J. W. M. Rudd, C. A. Kelly, K. G. Beaty, N. S. Bloom, and R. J. Flett. 1994. Importance of wetlands as sources of methyl mercury to boreal forest ecosystems. Canadian Journal of Fisheries and Aquatic Sciences 51: 1065-1076.

St. Louis, V. L., J. W. M. Rudd, C. A. Kelly, K. G. Beaty, R. J. Flett, and N. T. Roulet. 1996. Production and loss of methylmercury and loss of total mercury from Boreal Forest catchments containing different types of wetlands. Environmental Science and Technology 30: 2719-2792.

Swain, A. M. 1973. A history of fire and vegetation in northeastern Minnesota as recorded in lake sediments. Quaternary Research 3: 383-396.

Syncrude Canada. 1998. The Mildred Lake upgrader expansion. Environmental Impact Assessment, Volume IIa. Fort McMurray, Alberta, Canada. 
Urban, N. R., S. E. Bayley, and S. J. Eisenreich. 1989. Export of dissolved organic carbon and acidity from peatlands. Water Resources Research 25: 1619-1628.

Urquizo, N., T. Brydges, and H. Shear. 1998. Ecological assessment of the boreal shield ecozone. Environment Canada (Draft, August 1998). Burlington, Ontario, Canada.

Verry, E. S. 1986. Forest harvesting and water: the lake states experience. Water Resources Bulletin 22: 1039-1047.

Vitousek, P. M., J. D. Aber, R. W. Howarth, G. E. Likens, P. A. Matson, D. W. Schindler, W. H.

Schlesinger, and D. Tilman. 1997. Human alteration of the global nitrogen cycle: causes and consequences. Ecological Applications 7: 737-750.

Vollenweider, R. A. 1976. Advances in defining critical loading levels for phosphorus in lake eutrophication. Memorie dell'Istituto Italaliano di Idrobiologia 33: 53-83.

Wheatley, B., and S. Paradis. 1995. Exposure of Canadian aboriginal peoples to methylmercury. Water, Air, and Soil Pollution 80: 3-11.

Whittier, T. R., D. B. Halliwell, and S. G. Paulsen. 1997. Cyprinid distributions in northeast USA lakes: evidence of regional-scale minnow biodiversity losses. Canadian Journal of Fisheries and Aquatic Sciences 54:1593-1607.

Wright, H. E., and M. L. Heinselman. 1973. The ecological role of fire in natural conifer forests of western and northern North America - Introduction. Quaternary Research 3: 319-328.

Wright, R. F. 1976. The impact of forest fire on the nutrient influxes to small lakes in northeastern Minnesota. Ecology 57: 649-663.

Yan, N. D., W. Keller, N. M. Scully, D. R. S. Lean, and P. J. Dillon. 1996. Increased UV-B penetration in a lake owing to drought-induced acidification. Nature $\mathbf{3 8 1}$ : 141-143.

Yan, N. D., and T. W. Pawson. 1997. Changes in the crustacean zooplankton community of Harp Lake, Canada, following invasion by Bythotrephes cederstroemi. Freshwater Biology 37: 409-425.

Yan, N. D., T. W. Pawson, and L. E. Mackay. 1992. Bythotrephes cederstroemi (Schoedler) in Muskoka lakes: first records of the European invader in inland lakes in Canada. Canadian Journal of Fisheries and Aquatic Sciences 49: 422-426.

\section{Address of Correspondent:}

David W. Schindler

Department of Biological Sciences

University of Alberta

Edmonton, Alberta

Canada T6G 2E9

Phone: (403) 492-1291

Fax: (403) 492-9234

d.schindler@ualberta.ca

*The copyright to this article passed from the Ecological Society of America to the Resilience Alliance on 1 January 2000. 